\title{
A method of sterilizing and preserving fresh allograft heart valves
}

\author{
EUNICE L OCKEY, NAWAL AI-JANABI, \\ LORENZO GONZALEZ-LAVIN ${ }^{1}$, and D. N. ROSS \\ Departments of Clinical Pathology and Surgery, National Heart Hospital, and \\ Institute of Cardiology, London
}

\begin{abstract}
The present study was undertaken to find an antibiotic mixture which would rapidly and completely sterilize a heavily contaminated allograft heart valve without reducing its viability. Two different antibiotic combinations were used; formula A was used for 66 valves and formula B for 60 valves. Viability of the valves was assessed by autoradiography and tissue culture, and was found to be similar in both formulae. Formula B proved more effective ; all valves were sterile after 24 hours' exposure to the antibiotics and remained so thereafter.

The period of viability was greatly extended when a nutrient medium was used to store the valves.
\end{abstract}

The perfect design, absence of thromboembolism, and excellent haemodynamics have established the allograft valve as one of the best substitutes for diseased heart valves (Barratt-Boyes, Roche, and Cole, 1969b; Karp and Kirklin, 1969; GonzalezLavin and Ross, 1970a; Wallace, Giuliani, and Titus, 1971). Accumulated evidence indicates that the long-term function of these valves depends primarily on the methods of sterilization and storage to which they have been subjected (Hudson, 1966; Smith, 1967; Davies et al., 1968). More recent experience has shown that fresh allograft valves sterilized in antibiotics are superior to preserved grafts (Barratt-Boyes et al., 1969a; Barratt-Boyes and Roche, 1969; Gonzalez-Lavin and Ross, 1970b). These valves have living fibroblasts (Kosek, Iben, Shumway and Angell, 1969; Al-Janabi, Gonzalez-Lavin, Neirotti, and Ross, 1972) capable of remoulding and repairing the valve and therefore offer the possibility of a longterm replacement. Consequently, it is important to select a method that will sterilize and preserve allograft valves in a viable state.

The present study has been undertaken to find an antibiotic mixture which will rapidly and completely sterilize a heavily contaminated homograft heart valve without reducing its viability, as shown by tissue culture and autoradiography.

MATERIALS AND METHODS

Aortic allograft valves were obtained from necropsies performed in public mortuaries without any attempt at sterility. The time after death varied from 24 to 72 hours, and in some instances the heart was refrigerated for a further period of up to 24 hours before the valve was dissected out.

The trimmed valve was placed in the appropriate antibiotic mixture together with several small pieces of aortic wall. It was refrigerated at $4^{\circ} \mathrm{C}$ and after 24 and 72 hours pieces of aortic wall were removed with sterile precautions and placed separately in liquid media designed to encourage growth of aerobic and anaerobic micro-organisms and fungi. After incubation at $37^{\circ} \mathrm{C}$ for 24 and 72 hours, subcultures were made onto blood agar.

Two different antibiotic combinations were used. The first, formula $A^{2}$ used for 66 valves, was that described by Barratt-Boyes in 1969. We evolved formula $B$ when it became evident that the first formula was not suitable for the conditions under which our valves were collected. It was used for 60 valves.

Formula A

$\left.\begin{array}{lrr}\begin{array}{l}\text { Penicillin } \\ \text { Streptomycin }\end{array} & 50 & \text { units } / \mathrm{ml} \\ & 1 & \mathrm{mg} / \mathrm{ml} \\ \text { Kanamycin } & 1 & \mathrm{mg} / \mathrm{ml} \\ \text { Amphotericin B } & 25 & \mu \mathrm{g} / \mathrm{ml}\end{array}\right\}$ in Hank's solution

Formula $\mathbf{B}^{3}$

$\left.\begin{array}{lrr}\begin{array}{l}\text { Gentamicin } \\ \text { Methicillin }\end{array} & 4 & \mathrm{mg} / \mathrm{ml} \\ \begin{array}{l}\text { Erthromycin- } \\ \text { Lactobionate }\end{array} & 6 & \mathrm{mg} / \mathrm{ml} \\ \begin{array}{l}\text { Nystatin } \\ \mathrm{mg} / \mathrm{ml}\end{array}\end{array}\right\}$ in Hank's solution

1Please address all correspondence to: Lorenzo Gonzalez-Lavin, M.D., Institute of Cardiology, 2 Beaumont Street, London WiN 2DX

${ }^{2}$ Barratt-Boyes formula

3National Heart Hospital formula 
These antibiotics were prepared in $200 \mathrm{ml}$ quantities, being first made up in distilled water where necessary, the volume then being completed with Hank's solution (Hanks, 1948). Formula B was chosen to give the widest possible killing range with antibiotics present in high enough concentration to kill heavy inocula. They are all physically compatible and in sufficient volume to allow accurate measurement. Nystatin was chosen as the antifungal agent because of its cidal activity despite its lack of solubility; this accounts for the 'sludge' in the mixture.

Formula B antibiotics were also made up in a nutrient medium to see if this would extend the period of viability. The medium used was $199+10 \%$ fetal calf serum (Morgan, Morton, and Parker, 1950).

Viability was assessed using tissue culture and autoradiography, the latter having the advantage of being quantitative. For tissue culture, fragments of homograft were placed in Petri dishes, the bases of which had been scarified. Four millilitres of the nutrient medium $(199+10 \%$ fetal calf serum) were added and the dishes were incubated at $37^{\circ} \mathrm{C}$ in a plastic box after flushing with $5 \%$ carbon dioxide in air. The medium was changed every two days and was flushed each time. Growth was considered good if all pieces of tissue adhered to the base of the dish.

The autoradiography technique utilized a nutrient medium containing methyl tritiated thymidine. Pieces of tissue were incubated in it, any metabolically active fibroblast incorporating the labelled thymidine into its nucleus. Sections were cut and a thin film of Ilford K2 nuclear emulsion ${ }^{2}$ was layered over them. They were allowed to dry and were kept in a light-proof box for seven days at $5^{\circ} \mathrm{C}$. The beta rays emitted by the isotope on striking the emulsion produced a positive stain visible as a black grain on light microscopy. The number of nuclei which incorporate radioactive thymidine are then counted and a percentage of the viable cells is calculated.

\section{RESULTS}

STERILITY Formula A was used for the first 66 valves. Thirty-five valves were sterile after 24 hours' exposure to the antibiotics and remained so. The other $31(47 \%)$ were not sterile after 72 hours in the mixture and seven of these, which were followed for a longer period, were still not sterile after 10-14 days' exposure to the antibiotics. Thirty-four organisms in all were cultured (two different organisms from three heart valves) and were as follows:

\begin{tabular}{|c|c|}
\hline v & $\begin{array}{l}\text { ere Strep. faeca } \\
\text { ly Candida alb }\end{array}$ \\
\hline
\end{tabular}

Staphylococcus

Gram-negative bacillus 3

Gram-positive bacillus 2

1Supplied by Burroughs Wellcome 2IIford Ltd., Ilford, Essex
With formula B all valves were sterile after 24 hours' exposure to the antibiotics and remained so.

VIABILITY Pieces of homograft subjected to both antibiotic formulae in Hank's solution showed good growth in tissue culture for up to three weeks. Pieces sterilized with the National Heart Hospital formula in nutrient medium showed growth for up to five weeks.

Autoradiography also showed similar viability of valve tissue sterilized by either antibiotic formula in Hank's solution. Seventy per cent of the fibroblasts took up thymidine during the first 24 hours of storage followed by a steady decline in thymidine uptake which became more pronounced after 18 days (Fig. 1). Again, when a nutrient medium was used instead of Hank's solu-

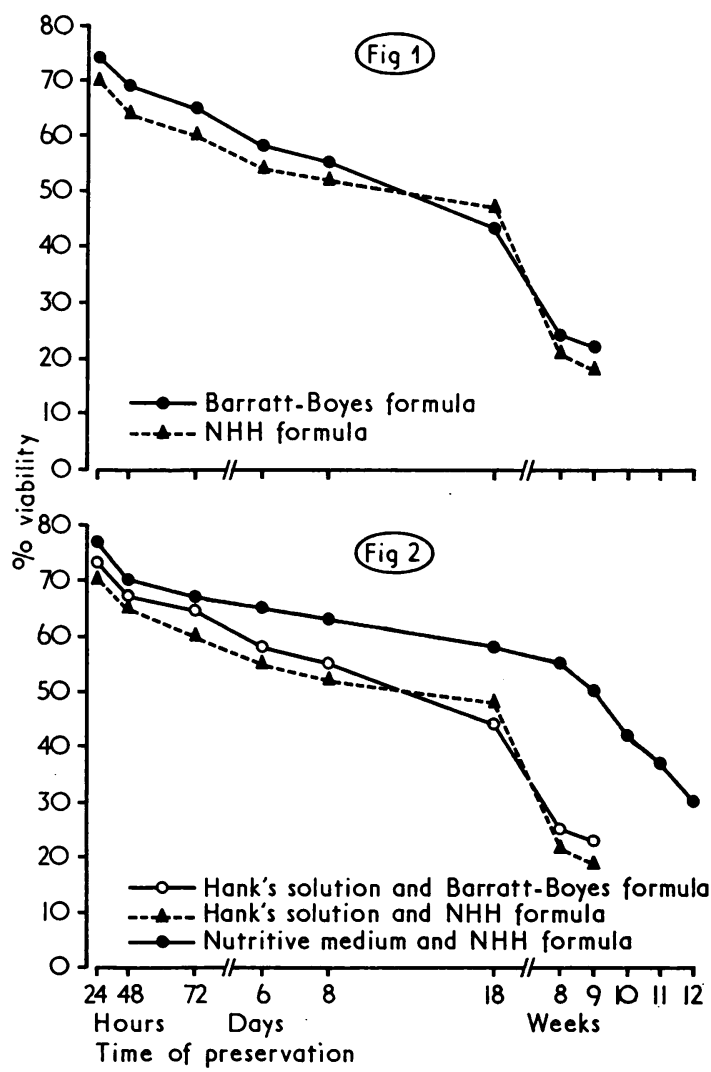

FIG. 1. Duration of survival of fibroblasts in valves stored in Hank's solution.

FIG. 2. Period of viability is greatly extended when the valves are stored in a nutritive medium. 
tion, the period of viability was greatly extended so that the percentage of viable cells at eight weeks in the former was the same as that at eight days in the latter (Fig. 2).

\section{DISCUSSION}

The aortic allograft valve with its perfect design ensures a central non-obstructive flow orifice with excellent haemodynamics. In addition, red cell damage and residual gradients are uncommon and the hazard of thromboembolism is virtually absent.

Ideally, the process of sterilization and storage should not alter the structure of the valve and, if possible, should preserve the graft in a viable state. A living valve should stand the wear-andtear of time and be able to replace its structure, assuring long-term function and, perhaps, a permanent replacement.

The valves collected in public mortuaries are heavily contaminated, as shown by culture before sterilization (Yacoub and Kittle, 1970; GonzalezLavin, 1971). An antibiotic combination effective against the widest possible range of microorganisms is essential. At the same time they must not alter the structure of the graft nor interfere with their viability. Although formula A antibiotics preserved valves in a viable state, they sterilized only about half the valves collected under our conditions. The National Heart Hospital formula, on the other hand, yielded $100 \%$ of the valves sterile after 24 hours. In addition, the valves continued to show a high percentage of metabolically active fibroblasts for at least eight weeks of storage if a nutrient medium was used in place of Hank's solution.

We wish to thank Professor B. W. Lacey of the Westminster Hospital, London, for much helpful discussion, and Miss V. Adler for assistance in the preparation of this paper.

\section{REFERENCES}

Al-Janabi, N., Gonzalez-Lavin, L., Neirotti, R., and Ross, D. N. (1972). Viability of fresh aortic valve homografts: a quantitative assessment. Thorax, 27, 8?.

Barratt-Boyes, B. G., and Roche, A. H. G. (1969). A review of aortic valve homografts over a six and one-half year period. Ann. Surg., 170, 483.

- Brandt, P. W. T., Smith, J. C., and Lowe, J. B. (1969a). Aortic homograft valve replacement. A longterm follow-up on an initial series of 101 patients. Circulation, 40, 763.

— a Cole, D. S. (1969b). Aortic homograft valve replacement: a review of 511 patients with a late followup extending to 65 months. J. cardiovasc. Surg., Special Issue: XVII Congress of the European Society of Cardiovascular Surgery, London, 1968, p. 18.

Davies, H., Missen, G. A. K., Blanford, G., Roberts, C. I., Lessof, M. H., and Ross, D. N. (1968). Homograft replacement of the aortic valve. A clinical and pathologic study. Amer. J. Cardiol., 22, 195.

Gonzalez-Lavin, L. (1971). Unpublished data.

- and Ross, D. N. (1970a). Homograft aortic valve replacement. A five year experience at the National Heart Hospital, London. J. thorac. cardiovasc. Surg., 60, 1 .

- and - (1970b). Homotransplantation of the aortic valve. Verh. dtsch. Ges. Kreisl.-Forsch., 36, 39.

Hanks, J. H. (1948). The longevity of quick tissue cultures without renewal of medium. J. cell. comp. Physiol., 31, 235.

Hudson, R. E. B. (1966). Pathology of the human aortic valve homograft. Brit. Heart J., 28, 291.

Karp, R. B., and Kirklin, J. W. (1969). Replacement of diseased aortic valves with homografts. Ann. Surg., 169, 921.

Kosek, J. C., Iben, A. B., Shumway, N. E., and Angell, W. W. (1969). Morphology of fresh heart valve homografts. Surgery, 66, 269.

Morgan, J. F., Morton, H. J., and Parker, R. C. (1950). Nutrition of animal cells in tissue culture. 1. Initial studies on synthetic medium. Proc. Soc. exp. Biol. (N.Y.), 73, 1.

Smith, J. C. (1967). Pathology of human aortic valve homografts. Thorax, 22, 114.

Wallace, R. B., Giuliani, E. R., and Titus, J. L. (1971). Use of aortic valve homografts for aortic valve replacement. Circulation, 43, 365.

Yacoub, M., and Kittle, C. F. (1970). Sterilization of valve homografts by antibiotic solutions. Circulation, Suppl. II to Vol. 41 and 42, 29. 